\title{
Early Metabolic Defects in The First-Degree Relatives of Patients with Non-Insulin-Dependent Diabetes Mellitus
}

\author{
Wilfried Herdin Sibuea
}

\begin{abstract}
Abstrak
Delapan puluh lima persen dari penderita diabetes adalah Diabetes Melitus Tidak Tergantung Insulin (DMTTI), yang diduga timbul akibat interaksi antara faktor genetik dan paparan terhadap faktor luar.Tujuan penelitian ini ialah untuk mengidentifikasi kelainan metabolik pada anak penderita DMTTI di Indonesia yang diharapkan dapat bermanfaat untuk upaya pencegahan. Sebanyak 55 orang anak penderita DMTTI dan 55 orang kontrol yang sehat tanpa riwayat diabetes dalam keluarga ikut dalam penelitian ini. Kedua kelompok mempunyai umur, jenis kelamin dan indeks massa tubuh yang sama. Dilakukan tes toleransi glukosa oral untuk menilai toleransi glukosa dan untuk menilai respons insulin terhadap glukosa oral. Darah vena diambil sebelum dan 2 jam setelah pembebanan glukosa untuk menentukan kadar glukosa dan insulin plasma. Terdapat beberapa perbedaan yang bermakna antara anak penderita DMTTI dan kontrol. Pada anak penderita DMTTI terdapat 7 orang mengidap toleransi glukosa terganggu (TGT), sedang pada kontrol hanya 1 kasus. Untuk mempertahankan agar kadar glukosa darah tetap normal, anak penderita DMTTI memerlukan kadar insulin yang lebih tinggi dibanding kelompok kontrol (rasio I/G $0.5 \mathrm{vs}$ 0.3). Kadar insulin plasma lebih tinggi bermakna pada anak penderita DMTTI dibanding kontrol. Dari penelitian ini ditemukan bahwa TGT, hiperinsulinemia dan resistensi insulin merupakan kelainan metabolik yang ditemukan pada tahap dini pada anak penderita DMTTI di Indonesia.
\end{abstract}

\begin{abstract}
Non-Insulin-Dependent Diabetes Mellitus (NIDDM) constitutes about $85 \%$ of all cases of diabetes worldwide and appears to be the consequence of an interaction between genetic susceptibility and exposure to environmental factors. The purpose of this study is to identify early metabolic defects in the first-degree relatives of patients with NIDDM in Indonesia, which may be useful in the strategies for early prevention. Fifty-five healthy first-degree relatives of patients with NIDDM and 55 healthy control subjects with no family history of NIDDM, matched for age, gender and body mass index participated in this study. Oral glucose tolerance test was used to assess glucose tolerance and to measure the insulin response to oral glucose. Venous blood samples were taken before and 120 minutes after glucose was administered for plasma glucose and insulin determination. Several characteristics of metabolic abnormalities distinguished the first-degree relatives of patients with NIDDM from control subjects. They needed higher insulin to maintain the normal plasma glucose than did the control subjects (I/G ratio 0.5 vs 0.3 ). They had 7 (12\%) impaired glucose tolerance cases and only 1 in the control subjects. The fasting plasma insulin level was higher in the relatives of NIDDM with normal glucose tolerance (NGT). This study shows that IGT, hyperinsulinemia and insulin resistance are important early metabolic defects among the first-degree relatives of patients with NIDDM in Indonesia.
\end{abstract}

Keywords: First degree relatives of patients with NIDDM, insulin resistance, hyperinsulinemia

Non-Insulin-Dependent Diabetes Mellitus (NIDDM) constitutes about $85 \%$ of all cases of diabetes worldwide and is associated with an enormous amount of morbidity and mortality resulting from microvascular and macrovascular complications. ${ }^{1,2}$

Department of Internal Medicine, Faculty of Medicine, University of Indonesia, Dr. Cipto Mangunkusumo Hospital, Jakarta, Indonesia
The high incidence of NIDDM among first-degree relatives of NIDDM patients and high concordance in identical twins provide evidence that the role of genetic component in the development of NIDDM is very strong. ${ }^{1}$ The disease is characterized by defect in pancreatic beta cell function and the resistance of the tissues to the action of insulin. ${ }^{2}$

The development of NIDDM among the offspring of diabetic parents is preceded and predicted by defect in both insulin dependent and insulin independent glucose uptake of the tissues ${ }^{3}$ and 10-25 years before NIDDM is diagnosed in the normal offspring of 
diabetic parents, insulin resistance and hyperinsulinemia are already present. ${ }^{4}$ Apparently, both insulin resistance and impaired insulin secretion are necessary of the development of the disease. ${ }^{5}$

The purpose of this study is to identify early metabolic defects in the first-degree relatives of patients with NIDDM in Indonesia, which may be useful in the strategies for the prevention of NIDDM.

\section{METHOD}

Fifty-five healthy first-degree relatives of patients with NIDDM and 55 healthy control subjects with no family history of NIDDM, matched for age, gender and body mass index participated in this study. At the time of recruitment, no relatives or control subjects had a disease or received medications known to affect glucose metabolism.

\section{Oral Glucose Tolerance Test}

A 75 gram oral glucose tolerance test was performed to assess glucose tolerance and to measure the insulin response to oral glucose. After a 12 hour overnight fast, all subjects were given a 75-g oral glucose load. Venous blood samples were taken before and 120 minutes after the glucose was administered for determination of plasma glucose and serum insulin concentrations.

Diagnosis of impaired glucose tolerance (IGT) was established if the fasting plasma glucose (FPG) was $<140 \mathrm{mg} / \mathrm{dl}$ and plasma glucose 2 hours after glucose load (2-h PG) ranged between 140-200 mg/dl. NIDDM was diagnosed if FPG was $\geq 140 \mathrm{mg} / \mathrm{dl}$ or $2-\mathrm{h} \mathrm{PG}$ was $\geq 200 \mathrm{mg} / \mathrm{dl}{ }^{5}$ Insulin resistance as stated by Berson and Yalow is defined as a state of a body in which greater-than-normal amounts of insulin are required to elicit a quantitatively normal respons. ${ }^{6}$ It was determined by the method of Yalow and Berson with modification. The ratios of plasma insulin and plasma glucose (fasting I/G, 2 hours I/G, total I/G ratio) were calculated in each group and was interpreted as the higher the ratio the greater the insulin resistance. ${ }^{7}$

\section{Assays and Statistical Analysis}

Plasma glucose was assayed with a glucose oxidase method (GOD PAP). The plasma insulin concentration was measured using DPC reagents Coat-A-Count according to standard Radioimmunoassay procedure ${ }^{8}$ performed by Immunoendocrinology Laboratory, School of Medicine, University of Indonesia, WHO Laboratory no. 104 for Matched Reagent Programme and no. 21 Zone B for External Quality Control.

All data were expressed as mean \pm SD. All statistical analysis were performed by using SPSS for windows. Linear regression analysis was used to estimate the required insulin amounts to elicit normal glucose levels at 2 hours after glucose ingestion. Independent t-test was used to test the differences between two means.

\section{RESULTS}

A total of 110 persons were studied : 55 first degree relatives of patients with NIDDM and 55 healthy control subjects with no family history of NIDDM.

The age, the body mass index (BMI), the number of male and female subjects were similar in both groups (Table 1).

Table 1. Characteristics of the Study Subjects

\begin{tabular}{lccc}
\hline Characteristics & $\begin{array}{c}\text { Relatives of } \\
\text { NIDDM patients }\end{array}$ & Control subjects & $p$ \\
\hline No. subjects & 55 & 55 & 1 \\
Gender & $17 \mathrm{M}, 38 \mathrm{~F}$ & $17 \mathrm{M}, 38 \mathrm{~F}$ & 1 \\
Age (years) & $31.6 \pm 10.4$ & $31.6 \pm 9.9$ & 0.9 \\
BMI & $23.8 \pm 3.8$ & $22.5 \pm 3.9$ & 0.08 \\
\hline
\end{tabular}

Among the metabolic characteristics that were studied, there were several differences between the groups (Table 2).

Table 2. Results of Oral Glucose Tolerance Test

\begin{tabular}{lccc}
\hline Item & $\begin{array}{c}\text { Relatives of patients } \\
\text { with NIDDM }\end{array}$ & $\begin{array}{c}\text { Control } \\
\text { subjects }\end{array}$ & $p$ \\
\hline Impaired glucose tolerance & 7 & 1 & 0.03 \\
Fasting plasma glucose*) & $85.1 \pm 11.4$ & $79.4 \pm 10.5$ & 0.007 \\
2 hour plasma glucose & $106.5 \pm 27.9$ & $95.9 \pm 18.2$ & 0.02 \\
Fasting plasma insulin**) & $13.2 \pm 6.4$ & $9.9 \pm 5.1$ & 0.004 \\
2 hour plasma insulin & $84.6 \pm 63$ & $48.9 \pm 52$ & 0.0001 \\
\hline *) Plasma glucose in mg/dl & $* *$ ) Plasma insulin in mU/L &
\end{tabular}

The relatives of patients with NIDDM had higher IGT cases than the control subjects ( 7 cases.vs 1 case), and they had also higher FPG and 2-h PG. 
The relatives of NIDDM patients with normal glucose tolerance (NGT) had higher plasma glucose and plasma insulin levels than the control subjects (Table 3 ).

By calculating the ratio of plasma insulin and plasma glucose in each group, it was found that to maintain a normal plasma glucose level, higher plasma insulin concentration was needed by the relatives with NGT than by control subjects (fasting I/G was 0.16 vs $0.12,2$ hour $\mathrm{U} / \mathrm{G}$ was 0.8 vs 0.48 , and total $\mathrm{I} / \mathrm{G}$ was 0.5 vs 0.3 ).

This greater insulin requirement was caused by the presence of insulin resistance in this group. (Figure 1).
The relatives of NIDDM patients with NGT had 2 hour plasma insulin and plasma glucose levels higher than those observed in the control subjects. By linear regression analysis the need of insulin amounts to elicit normal glucose levels could be quantified (Fe level the amount of the insulin requirement was $88,56 \mathrm{mU} / \mathrm{I}$ in the relatives with NGT and $51 \mathrm{mU} / \mathrm{I}$ in the control subjects. While at $115 \mathrm{mg} / \mathrm{dl}$ it was $91,6 \mathrm{mU} / \mathrm{I}$ and 66 $\mathrm{mU} / \mathrm{I}$ respectively. Thus there is insulin resistance in the relatives of NIDDM patients with NGT.

Table 3. Comparison of plasma glucose and insulin level in the first degree relatives of patients with NIDDM and control subjects based on glucose tolerance

\begin{tabular}{llccccc}
\hline \multirow{2}{*}{\multicolumn{1}{c}{ Item }} & \multicolumn{3}{c}{ normal glucose tolerance } & \multicolumn{3}{c}{ impaired glucose tolerance } \\
\cline { 2 - 6 } & relatives & control & $p$ & relatives & control & $p$ \\
\hline Fasting plasma glucose*) & $83.3 \pm 10$ & $79 \pm 11$ & 0.0 & $396.7 \pm 14$ & 79 & 0.2 \\
2 hour plasma glucose & $98.4 \pm 15$ & $93.8 \pm 16$ & 0.14 & $162.1 \pm 3$ & 164 & 0.5 \\
Fasting plasma insulin**) & $13.1 \pm 6$ & $9.8 \pm 5.2$ & 0.004 & $14.7 \pm 6$ & 11.8 & 0.5 \\
2 hour plasma insulin & $82 \pm 64.6$ & $47.5 \pm 51.9$ & 0.002 & $115.5 \pm 42$ & 57.7 & 0.3 \\
\hline
\end{tabular}

*) Plasma glucose in $\mathrm{mg} / \mathrm{dl}$

**) Plasma insulin in $\mathrm{mU} / \mathrm{L}$

\section{Insulin/glucose ratio}

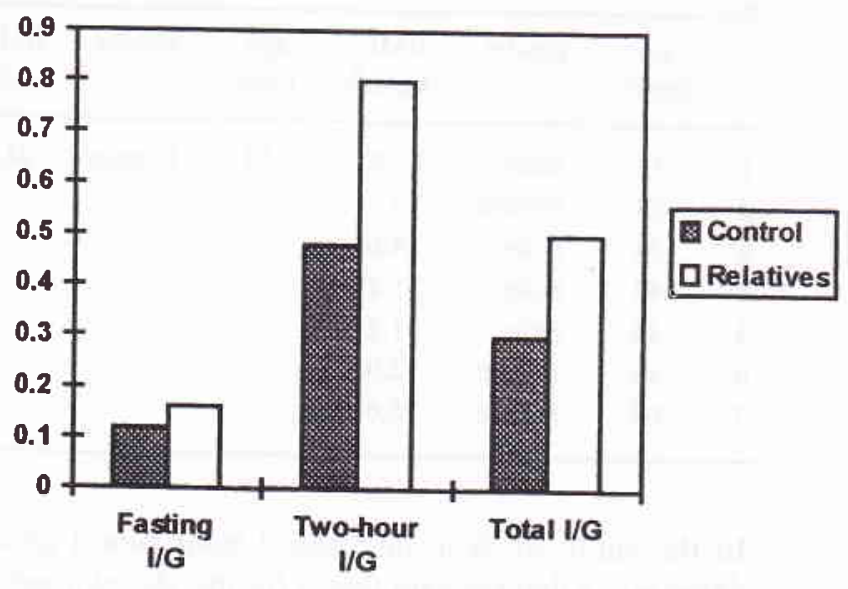

Figure 1. The ratio of plasma insulin and plasma glucose in relatives of NIDDM patients with normal glucose tolerance and in control subjects. 


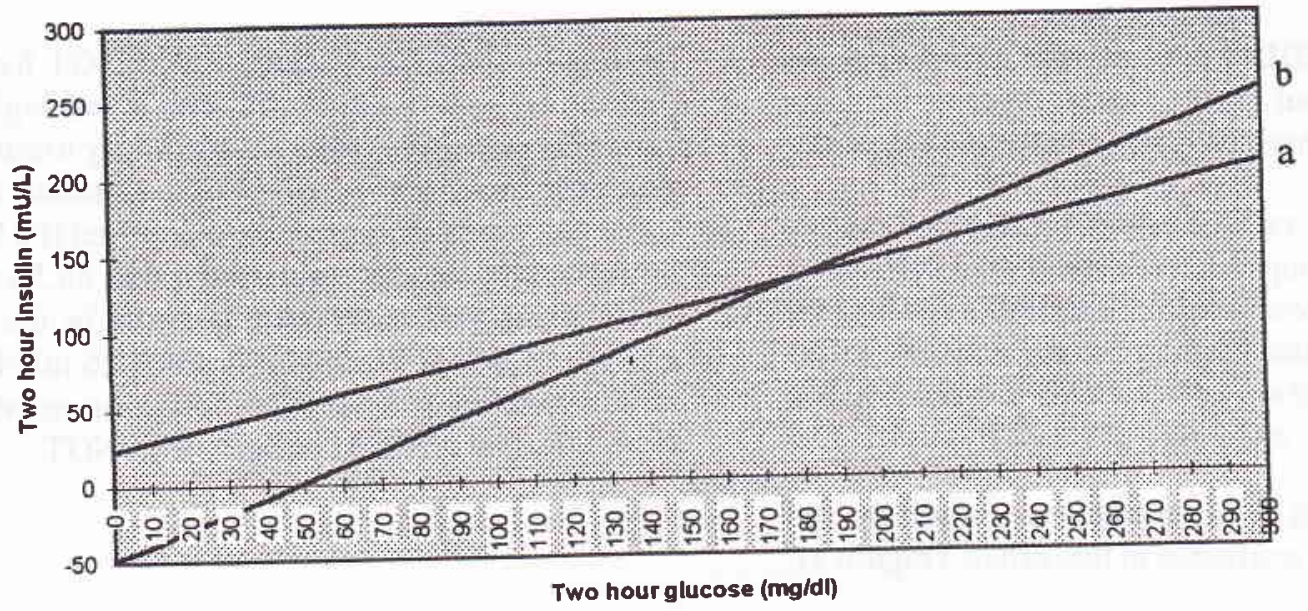

Figure 2. Two hour plasma insulin level as a fuction of 2 hour glucose level in the relatives of NIDDM patients with normal glucose tolerance $(a)$ and the control subjects $(b)$. Line $(a): y=22,56+0,6($ glucose) and line $(b): y=-49+1$ (glucose) represent the regression slope of 2 hour insulin against 2 hour glucose levels.

Fasting plasma insulin in the relatives of patients with NIDDM was significantly higher than in the control subjects $(13.5 \pm 6.4$ vs $9.7 \pm 5 \mathrm{mU} / \mathrm{l}, \mathrm{p}=0.001)$. As the age, BMI and gender were evenly matched between the two groups, this hyperinsulinemic difference can be regarded as a result of metabolic defects in the relatives of patients with NIDDM.

Likewise as shown in Figure 3, the insulin level 2 hours after glucose load was significantly higher in the relatives of patients with NIDDM than in control subjects $(86.9 \pm 62.7$ vs $47 \pm 51.2 \mathrm{mU} / \mathrm{l}, \mathrm{p}=0.00002)$.

\section{$\mathrm{mU} / 1$}

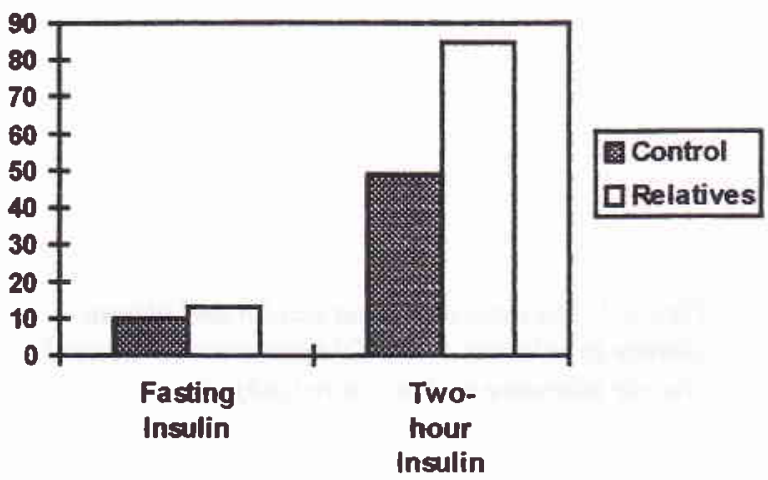

Figure 3. Comparison of fasting plasma insulin and 2 hour plasma insulin between first degree relatives of patients with NIDDM and control subjects.

\section{DISCUSSION}

Longitudinal studies of the development of NIDDM reported in the literature revealed that plasma glucose concentration is the overwhelming risk factor long before the occurrence of the disease. ${ }^{5,6}$

Saad et $\mathrm{al}^{8}$ reported that $25 \%$ of the IGT subjects developed NIDDM at 5 years and $66 \%$ at 10 years. In this study there were 7 cases of IGT in the relatives of NIDDM patients and 1 in the control subjects. Their baseline data were shown in Table 4. It was clear that IGT in the relatives of NIDDM patients was not age or BMI dependent. These IGT cases have a risk of developing NIDDM.

Table 4. Baseline data of the Impaired Glucose Tolerance subjects

\begin{tabular}{lllllll}
\hline & \multicolumn{3}{c}{ Relatives } & \multicolumn{3}{c}{ Control } \\
\cline { 2 - 6 } & $\begin{array}{c}\text { age } \\
\text { (year) }\end{array}$ & gender & $\begin{array}{c}\text { BMI } \\
\left(\mathrm{kg} / \mathrm{m}^{2}\right)\end{array}$ & $\begin{array}{c}\text { age } \\
\text { (year) }\end{array}$ & gender & $\begin{array}{c}\text { BMI } \\
\left(\mathrm{kg} / \mathrm{m}^{2}\right)\end{array}$ \\
\hline 1 & 17 & male & 21.8 & 51 & female & 24.2 \\
2 & 33 & female & 22 & & & \\
3 & 34 & male & 24.6 & & & \\
4 & 43 & male & 31.25 & & & \\
5 & 44 & male & 31.2 & & & \\
6 & 48 & female & 22.9 & & & \\
7 & 60 & female & 26.6 & & & \\
\hline
\end{tabular}

In the study of Warram, ${ }^{4}$ the 2 hour blood glucose value was a determinant factor for the development of type II diabetes mellitus (relative risk $=3.5$ ). $\mathrm{He}$ followed up 155 offspring of diabetic parents for 13 years and found $16 \%$ (25 subjects) of them developed type 
II diabetes. Those subjects who later became diabetes had at the initial visit higher 2-h PG values than did the others $(5.7 \pm 0.5 \mathrm{mM}$ blood glucose $=102.9-120.8$ $\mathrm{mg} / \mathrm{dl}$ plasma glucose). In the current study there were 13 subjects in the first degree relatives of patients with NIDDM who had 2-h PG higher than $120.8 \mathrm{mg} / \mathrm{dl}$. Based on the finding of Warram, those 13 subjects have a great risk to develop NIDDM.

In this study hyperinsulinemia was obviously found in the first-degree relatives of patient with NIDDM because their fasting as well as 2 hours plasma insulin were higher compared to control subjects. The same result was found by Erickson, ${ }^{5}$ Haffner ${ }^{7}$ and Warram. ${ }^{4}$ As there is no beta cell dysfunction in the relatives with NGT and IGT, the presence of hyperinsulinemia in these groups can also be regarded as a reflection of insulin resistance. $^{2}$

Insulin resistance is defined as a state of a body in which greater-than-normal amounts of insulin are required to elicit a quantitatively normal response. This definition applies to both insulin-treated diabetic patients and to those individuals in whom glucose tolerance is normal or near normal as a result of compensatory hyperinsulinemia. ${ }^{6,9}$ It is clear that insulin plays a greater role and is a dependent factor in the definition of insulin resistance state. In this study the insulin resistance was determined by the method of Yalow and Berson with modification. The ratio of insulin and glucose ( I/G ratio) was calculated instead of $\mathrm{G} / \mathrm{I}$ ratio and was interpreted as the higher the ratio the greater the insulin resistance. ${ }^{6}$ The relatives of NIDDM patients with normal glucose tolerance (NGT) had higher plasma glucose and plasma insulin levels than the control subjects (Figure 4). The ratios of insulin and glucose consistently showed that the relatives of NIDDM patients had higher $\mathrm{I} / \mathrm{G}$ ratio which meant they needed more insulin to maintain a normal glucose level. So it may be presumed that this group has insulin resistance.

The relatives of NIDDM patients with NGT had 2 hour plasma insulin and plasma glucose levels higher than in the control subjects (Figure 4). As the plasma glucose levels were nearly equal after glucose ingestion in both groups, while the resultant insulin concentrations were greater in the relatives of NIDDM patients with NGT then according to the definition this group was presumed to have insulin resistance. By linear regression analysis this insulin resistance could be quantified (Figure 2).

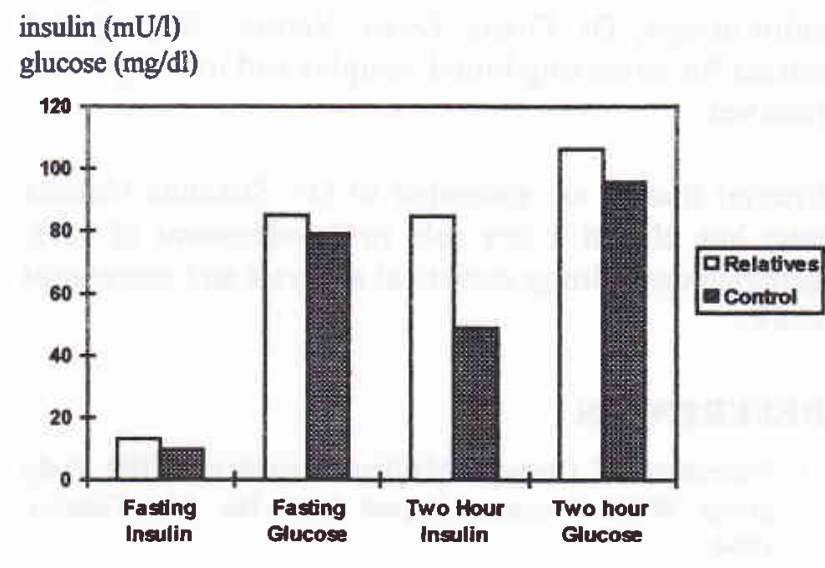

Figure 4. The comparison of fasting and 2-hour plasma insulin, fasting and 2-hour plasma glucose in relatives of NIDDM patients with normal glucose tolerance and in control subjects.

Various methods of measuring insulin action in-vivo have been proposed. In this study the insulin resistance was determined indirectly by using the modified Yalow-Berson method and linear regression analysis. The gold standard for insulin resistance determination is euglycemic clamp technique in which insulin is infused systemically and plasma glucose is maintained constant by exogenous glucose infusion. Glucose is clamped at euglycemia level. Glucose infusion rate equals sum of decrease in hepatic glucose release and increase in glucose uptake. ${ }^{13}$ By this method, Ndraha found higher insulin resistance in the overweight Indonesian NIDDM subjects and there was a significant correlation between BMI and fasting insulin level. ${ }^{14}$

In summary, this study shows that IGT, hyperinsulinemia and insulin resistance are important early metabolic defects among first-degree relatives of patients with NIDDM in Indonesia. Those IGT subjects and the relatives with NGT who have $2 \mathrm{~h}-\mathrm{PG}$ higher than $120.8 \mathrm{mg} / \mathrm{dl}$ are at increased risk of developing diabetes and should have NIDDM prevention program to decrease insulin resistance, to promote and sustain pancreatic beta cell function (e.g. by programs of obesity reduction and the promotion of physical activity). ${ }^{1}$

\section{ACKNOWLEDGMENTS}

I thank Tebet Hospital for their support and the study families for their kind and patience. I also thank the 
Immunoendocrinology Laboratory School of Medicine, University of Indonesia for doing insulin assays; Dr. Diana, Dewi, Ventje, Sugeng and nurses for collecting blood samples and inviting study families.

Special thanks are extended to Dr. Suzanna Ndraha who has played a key role in development of idea, generate data, doing statistical analysis and secretarial works.

\section{REFERENCES}

1. Prevention of Diabetes Mellitus. Report of WHO study group. WHO Technical Report Series,No. 844; Geneva, 1994.

2. Weir GC, Leahy JL. Pathogenesis of non-insulin-dependent (type II) diabetes mellitus. In Kahn CR, Weir GC, eds. Joslin's Diabetes mellitus. $13^{\text {th }}$ ed. Philadelphia, Lea and Febiger 1994; 240-64.

3. Martin BC, Warm JH, Kroleswski AS, Bergman RN, Steldnes JS, Kahn CR. Role of glucose and insulin resistance in development of type II diabetes mellitus: results of a 25 year follow up study. Lancet 1992;340:925-9.

4. Warram JH, Martin BC, Krolewski AS, Steldnes JS, Kahn CR. Slow glucose removal rate and hyperinsulinemia precede the development of type II diabetes in the offspring of diabetic parents. Ann Intern Med 1990;113:909-15.

5. Eriksson J, Fransila-Kalkenki A, Estrand A. Early metabolic defects in persons at increased risk for non-insulin-dependent diabetes mellitus. N Engl J Med 1989; 321:337-43.
6. Berson SA, Yallow RS. Insulin 'antagonist' and insulin resistance. In: Ellenberg M, Rifkin H (eds). Diabetes mellitus: Theory and Practice. New York: McGraw-Hill, 1970; 388-423.

7. Yallow RS, Berson SA. Immunoassay of endogenous plasma insulin in man. J Clin Invest 1960; 39:1157-75.

8. Tsu TT, Herzenberg LA. Solid phase Radioimmune assays. In: Mishell BB, Shiigi SM (eds). Selected Methods in Cellular Immunology. San Fransisco : Freeman and Co, 1980; 373-97.

9. Flier JS. An Overview of Insulin Resistance. In: Moller DE. Insulin Resistance. Chichester: John Willey and Sons, 1993; 1-7.

10. Charles MA, Fontbonne A, Thibult N, Warnet JM, Rosselin GE, Eschwege E. Risk factors for NIDDM in white population. Paris Prospective Study. Diabetes 1991;40:996-9.

11. Haffner SM, Stem MP, Hazuda HP, Pugh JA, Patterson JK. Hyperinsulinemia in a population at high risk for non-insulin-dependent diabetes mellitus. N Engl J Med 1986;315:220-4.

12. Saad MF, Knowler WC, Pettitt DJ, Nelson RG, Mott DM, Bennett PH. The natural history of impaired glucose tolerance in the Pima Indians. N Engl J Med 1988; 319:1500-6.

13. De Fronzo RA, Tobin JD, Andres R. Glucose Clamp Technique: a method for qualifying insulin secretion and resistance. Am J Physiol 1979;273:E214-23.

14. Ndraha S, Soewondo P, Suyono S. Resistensi insulin pada diabetes melitus tidak tergantung insulin berat badan lebih. Paper akhir Program Studi Spesialis bidang Ilmu Penyakit Dalam Jakarta, 1996. 